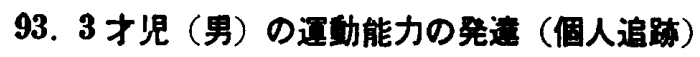

拓殖大学 加藤 芳 雄

1.はじめにこの研究は 3 才男児一個人をは注良好 な運動生活環境に一年間（実質は 2 才より 2 年間）打い て身体運動がどのように発達するかを観察した事例研究 である.

2. 研究方法 走, 跳, 投捕, 打, 䟽, 持久, 筋力, けん垂, バランス拉よび複合運動・その他の動作に分け て観察した.

3. 成绕 運動の成績を若干例示すると下のようであ る.

$4 \mathrm{~m}$ 走は誕生月 1.6 秒，3才 11 月 1.4 秒 $12 \%$ 向上し た.この成績は成人と同じ位である. $25 \mathrm{~m}$ 走は誕生月 7.5 秒，3才 11 月 6.5 秒で $15 \%$ 向上した. これは5才 児位の記録に相当する．石段昇降は 3 才では大人の仕方 では出来ない(武政, gesell) とされているが、被験者 は3才 1 月に高さ $17 \mathrm{~cm}$, 幅 $45 \mathrm{~cm}$ の 62 段の石段を大 人の仕方で我降した．また同月傾斜のゆるい石段を馸け て昇降した. 3才6月には10段の石段を冴けて昇降し 余裕があつた。

立幅跳は 3 才0月 $1.15 \mathrm{~m}, 3$ 才 10 月 $1.40 \mathrm{~m}$ で $25 \mathrm{~cm}$
延びた．この記録は 5 才児を上廻る. 走幅跳は 2.3 才で は出来ないとされているが，被験者は3才0月1.30m, 3才 11 月 $1.60 \mathrm{~m}$ を跳んだ．成績向上は $23 \%$ である. 垂直跳は 3 才 11 月 $30 \mathrm{~cm}$ を記録した。 これは小学校三 年位の記録に相当する。

軟式テニス ボール投は 3 才0月 $6 \mathrm{~m}, 3$ 才11月 $8 \mathrm{~m}$ を記録したが、これは4才児位であろう。

腕立伏臥腕屈伸は屈伸の程度は少ないが 3 才 7 月に 30 回行つた.

片足立ちは正常児は 3 才になるとほんの一橓間だけ一 本脚で立つことが出来る (武政)，また $3 才 6$ 月に 2 秒， 4 才で数秒 (gesell) とい5. 被験者は 3 才0月 8 秒, 3 才月 24 秒を記録した。

片眼つぶりは $4 \cdot 5$ 才までは決して出来ない（時実）と いわれているが，被験者は3才0月にそれが出来た。他 の例は省略する.

4. まとめ 運動の成績は1才乃至それ以上の年令層 に比敵した。これは 2 才の誕生月以降被験者を良い運動 生活環境においたためで，氏より育ちを重く見る著者の 意見をららつうける一资料となる。

\section{4. 幼児の基硭的通勤能力と固定遊具遊ひの技能} 長野県短期大学 降 旗 義 而

幼稚園教育要領に示してある運動の内容は走る，跳 ぶ、投げるなどの基整的運動能力と考えられるものがあ げられている.そこでこのような能力といろいらな遊び の技能が同じような条件下で獲得されてきているものと 仮定して，その間にどのような関係があるかを探り幼稚 園の運動内容を考える上の資料にしたいと考えて研究を すすめている.今回は固定遊具あそびに限定して行なつ た.

対象と方法 1966 年6月に運動能力を8月にあそび の技能を本学付属幼椎園 4.5 才児男女 120 名について測 定調查した. 運動能力は $2 \check{m}$ 走, 立幅跳, 硬式テニス ボール投，棒上片足立それにこ才児は握力を付加した。 あそびの技能は鉄棒前まわり，つり輪前まわり，はん登 棒登り，ら゙らんこ立乗り，雲梯前わたり，鉄棒さかあが りについて尺度点を設けて調査した。

結果 運動能力圷種目別の平均之標準偏差飞より 5 段 階区分し，個人别に種目別得点を加算して 総合得点と

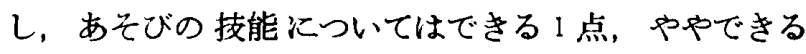
0.5 点,できない。点とし各種目の得点を個人別に総 㖕して成就度得点として，それらに生活年令（年令と略 称）および性を考溃して検討をした。

1. 総合得点と年令との間では相関係数 4 才男 0.565 女0.433，5才男0.693女0.410で男は1\%女は $5 \%$ 以 下の仜険率で有意であつた。

2. 成就度得点と年令とでは 4 才男 $0.401 \quad(\mathrm{P}<0.05)$ で相関係数は有意であつたが他はなかつた。

3. 成就度得点を 5 才照について男女で比較すると， 2〜3 点男 $23.3 \%$ 女 $10.3 \%, 4 \sim 5$ 点男 $66.3 \%$ 女 $44.8 \%$, 6点男 $13.3 \%$ 女 $44.8 \%$ で女が勝れていた（4才略）.

4. 総合得点と成就度得点とでは 4 才男 0.537 女 0.314 , 5 才男 0.517 女 0.321 で男には相関保数に有意 性がみられたが女にはなかつた，年令を除去した部分相 関では 5 才男と 4 才女に相関がみられ他にはなかつた。

以上から基礎的運動能力とあそびの技能ではかなり異 なる上達の様相がみられるといらことが推察された。 